\title{
ARTICLES
}

\section{IMPLEMENTATION OF HUDUD IN BRUNEI: DIFFERENCES BETWEEN BRUNEI AND MALAYSIA ${ }^{1}$}

\author{
Tun Abdul Hamid Mohamad*
}

\section{Introduction}

On 22 October 2013, the Government of Brunei Darussalam gazetted the Syariah Penal Code Order 2013 (the Order) with the view, in brief, to introduce the hudud and qisas punishments in the country. The Order has not been brought into force yet. It will be brought into force (or implemented) in stages, starting with takzir offences in April 2014. In the meantime, the provisions of the Penal Code will continue to be enforced and the offences tried by the Civil Courts. This is because the work of updating the relevant laws relating to procedure, evidence and others is still incomplete.

\section{The system of government and politics in Brunei}

Brunei is a "Malay, Islamic Monarchy". According to the Constitution of Brunei, Islam is the official religion of Brunei and the Sultan is the Head of the Official Religion in Brunei. He may, after consultation with the Religious Council, but not necessarily in accordance with the advice of the Council, make laws in respect of matters relating to the Islamic religion. ${ }^{3}$

The Sultan is the supreme executive authority of Brunei. He is the Prime Minister. Executive power is exercised by him. He is also the Supreme Commander of the Royal Brunei Armed Forces. He may appoint as many Ministers who shall be responsible solely to him for the exercise of executive authority. The Ministers' appointments may be revoked without giving any reason. ${ }^{4}$

There is a Privy Council whose members consist of the Deputy Sultan, the Regents (in both cases, if such appointments have been), ex-officio members and other persons appointed by the Sultan. ${ }^{5}$ The function of the Privy Council, inter alia, is to advise the Sultan on any amendment, addition or revocation of any provision of the Constitution. However, he is not bound to act in accordance with the advice of the Privy Council. ${ }^{6}$

Brunei Constitution provides for the establishment of the Council of Ministers ${ }^{7}$ whose members consist of the Prime Minister (the Sultan himself) and the Ministers appointed by the Sultan. ${ }^{8}$ Every Minister holds his seat in the Council of Ministers during the pleasure of the Sultan. ${ }^{9}$ No decision of the Council of Ministers is 
valid unless it is approved by the Sultan. ${ }^{10}$ In the exercise of his powers and the performance of his duties, the Sultan, subject to exceptions, is required to consult with the Council of Ministers. ${ }^{11}$ The Sultan is not bound to act in accordance with the advice of the Council of Ministers, but in any such case, he is required to record in writing the reason for his decision, for inclusion in the minutes. ${ }^{12}$

Brunei Constitution also provides for a Legislative Council. ${ }^{13}$ It has 45 members, 30 of whom are appointed by the Sultan, while 15 others are elected members. All members of the Council hold their positions during the pleasure of the Sultan. ${ }^{14}$ However, since the declaration of emergency in 1962 there had been no elections and all the members of the MMN are appointed by the Sultan. The MMN was reconvened in 2004 after being suspended since 1984. It meets annually since then for a 3-4 weeks' session per year. ${ }^{15}$

The Constitution gives the power to the Sultan to declare a state of emergency. ${ }^{16}$ The emergency declaration made in 1962 is still in force until now. During the emergency, the Sultan may make any order whatsoever which he considers desirable in the public interest to do so. These include "modification, amendment, supersession or suspension of all or any of the Provisions of any written law." 17 The Syariah Penal Code Order 2013 is one such order.

Article 84, Clause (2) provides:

(2) Nothing in this Constitution shall be deemed to derogate from the prerogative powers and jurisdiction of His Majesty the Sultan and Yang Di-Pertuan and, for the avoidance of doubt, it is declared that His Majesty the Sultan and Yang Di-Pertuan retains the power to make laws and to proclaim a further Part or Parts of the law of this Constitution as to His Majesty the Sultan and Yang Di-Pertuan from time to time may seem expedient.

This is followed by Article 84A as follows:

84B. (1) His Majesty the Sultan and Yang Di-Pertuan can do no wrong in either his personal or any official capacity. His Majesty the Sultan and Yang Di-Pertuan shall not be liable to any proceedings whatsoever in any court in respect of anything done or omitted to have been done by him during or after his reign in either his personal or any official capacity.

Article $84 \mathrm{C}$ (1) provides that the remedy of judicial review is and shall not be available in Brunei Darussalam. Clause (3) goes on to elaborate that no suit or action may be brought

relating to or arising out of any act, decision, grant, revocation or suspension, or refusal or omission to do so, any exercise of or refusal 
or omission to exercise any power, authority or discretion conferred on His Majesty the Sultan and Yang Di-Pertuan, or any party acting on his behalf or under his authority or in the performance of any public function, under the provisions of this Constitution or any written law or otherwise.

Article 85 empowers the Sultan, by Proclamation to amend, add to or revoke any of the provisions of the Constitution and the Constitution shall not otherwise be amended, added to or revoked. He is required to consult the Privy Council he is not bound to act in accordance with the advice of that Council.

It should be remembered that all these powers are applicable at all time.

Usually interpretation of the constitution is the function of the court. But, under the Constitution of Brunei the function is given to the Interpretation Tribunal consisting of three members appointed by the Sultan to hold office during his pleasure. $^{18}$

What are not mentioned in the Constitution of Brunei? The most notable are that there is no provision that says that the Constitution is the supreme law of the country and any law inconsistent with it is invalid. There are also no provisions on fundamental liberties, election, the judiciary or the Shari'ah courts.

In conclusion, first, the political system and government in Brunei is that of an absolute monarchy. Even under normal circumstances the Sultan has absolute executive and legislative powers. His powers supersede the provisions of the Constitution. Besides, he may also amend the Constitution or make laws regardless of the Constitution. In an emergency - and Brunei is under a state of emergency since 1962 - he may make law by an order the content of which may be inconsistent with the Constitution.

Secondly, Brunei is a unitary country and not a federation. There is no distribution of legislative powers between States and the Federation.

Thirdly, there is no constitutional limitation on the jurisdiction of the civil courts or the Shari'ah courts. For example, the Shari'ah courts' jurisdictions are not limited to persons professing the religion of Islam. There are no restrictions on the types of offences that can be placed under the jurisdiction of the Shari'ah courts e.g. the offences against the precepts of Islam or of the type of punishment that can be implemented by the Shari'ah courts. In any event the Sultan may either ignore or remove any restriction by amending the Constitution.

Fourthly, even though there are a few political parties in Brunei, they have no significant role to play. There is no coalition of political parties representing different races and religions to form the government, no general election and no opposition.

Under such circumstances, there is nothing or anyone that can prevent the Sultan if he is decides to make a law and implement it. 


\section{The system of government and politics in Malaysia}

Malaysia is a Federation. There are matters that lie within the jurisdiction of the Federal Legislature ${ }^{19}$ and there are matters that lie under the jurisdiction of the State Legislature. ${ }^{20}$ The Federal Constitution is the supreme law of the country and any law that is inconsistent with it is null and void. ${ }^{21}$

Government powers are shared by the three branches, the executive, the legislature and the judiciary. At the federal level, executive power rests with the Cabinet, led by the Prime Minister. The members of the Cabinet consist of members of the Dewan Rakyat elected in the general election. They belong to a coalition of parties that won a majority in the general election. (However, some Ministers are appointed from the appointed members of the Dewan Negara). In the final analysis, the Cabinet and the government are answerable to the voters who may even remove the government. The Yang DiPertuan Agong acts on the advice of the Cabinet. By convention, he must follow the advice of the Cabinet except in some matters provided for by the Constitution.

Legislative powers are vested in the Parliament consisting of the Dewan Rakyat, the Dewan Negara and the Yang DiPertuan Agong. Constitutional amendments require two-thirds majority. Apart from that there are matters that require the consent of the Conference of Rulers. Federal Parliament may only legislate on matters prescribed for it by the Constitution. It cannot legislate on matters that lie within the jurisdiction of the State Legislature.

Judicial powers are vested with the courts. These include power to interpret the Constitution and judicial review. Courts are empowered to declare a law, whether made by the federal or the state legislature, void if it conflicts with the Constitution. The court also has the power to declare an order, directive, decision or action of a Minister invalid through judicial review. This is usually done through an order of certiorari and habeas corpus. No one is above the law.

A state legislature may only legislate on matters that lie in List II of the Ninth Schedule (State List). Shari'ah Courts are State courts. Their jurisdictions are limited to Muslims only.

\section{How does Brunei propose to implement the Syariah Penal Code Order 2013?}

The law is made by an order issued during a state of emergency. It is made by the Sultan who has absolute power. No one can question him. No one can challenge him; not even through a court of law.

Until the Syariah Penal Code Order 2013 is brought into force, the position in Brunei is similar to that in Malaysia. Criminal offences are tried by the civil courts. In fact the Penal Code which is applied in Brunei is Macaulay's Penal 
Code, which was first introduced in India and then in Pakistan, Sri Lanka, Myanmar, Malaysia, Singapore and other British colonies. Offences such as murder, robbery, theft, rape and causing death and injury to human beings are provided in the Penal Code as punishable with death, imprisonment and fine as the case may be.

Similar to Malaysia, the so-called "Shari'ah offences" are placed under the jurisdiction of the Shari'ah courts. Indeed, in drafting the said laws Brunei used the Malaysian laws as a model. In fact, Brunei also adopted with modifications Malaysian laws on civil and criminal procedure, evidence and Islamic family law.

The Syariah Penal Code Order 2013 classifies offences as follows:

1. First, offences punishable with hudud punishments, for example, theft (sariqah), robbery (hirabah), adultery (zina), rape (zina bi'l-jabar), sodomy (liwat), accusing someone of adultery (qadhf), and drinking intoxicating drink.

2. Second, the offences punishable with qisas and diyat. For example, homicide (qatl) and causing hurt.

3. Third, general offences such as not performing Friday prayers, khalwat (close proximity between unrelated members of the opposite sex) and indecent acts which carry the sentence of imprisonment and fine (ta'zir).

Generally, the Order is applicable to both Muslims and non-Muslims, for example, offences of theft, robbery, rape and sodomy.

There are offences applicable to Muslims only, for example, drinking intoxicating drink and adultery.

There are offences applicable to non-Muslims only, for example, contempt of the Prophet (peace be upon him) by non-Muslims and deriding the verses of the Qur'an or Hadith by non-Muslims.

There are acts which do not constitute an offence if done by a non-Muslim with a non-Muslim, but becomes an offence if it is done with a Muslim, for example, adultery.

We shall now look at it from the perspective of jurisdiction. Some offences are under the exclusive jurisdiction of the Shari'ah Courts. For example, pregnant out of wedlock, failure to perform Friday prayers, disrespecting the month of Ramadan, khalwat, indecent behaviour, men posing as women or vice versa, practising black magic, propagation of religion other than the religion of Islam, worshipping contrary to hukum syarak and accusing a Muslim as kafir. These offences will be tried by the Shari'ah court. These are ta'zir offences punishable with imprisonment and/or fine.

There are also offences which have been in the Penal Code since its introduction in Brunei but now they are also provided for in the Shari'ah Penal Code Order 
2013. For example, theft, robbery, rape, sodomy, causing the death of another person and causing hurt. As a result, for these offences are similar provisions in two different laws with different means of proof, different sentences, different prosecutors and different courts to try them!

How are these offences dealt with? Where should the offences be reported, the police station or at the office of religious enforcement officers? Who will investigate the offences, the police or the religious enforcement officers? Who will prosecute; the Public Prosecutor or the Shari'ah Prosecutors? Which court will hear the cases, the civil court or the Shari'ah court?

According to the explanation given by Awang Haji Mohd. Yusree $\mathrm{Hj}$. Junaidi, the Assistant Solicitor General of Brunei, such cases will be reported to and investigated by the Royal Brunei Police Force, assisted by the Religious Enforcement Unit and other law enforcement agencies, if necessary.

Once the investigation is completed, the case would be forwarded to the Public Prosecutor. Assessment will be made, with the assistance of the Shari'ah Chief Prosecutor, if necessary, whether there is sufficient evidence for proving the offences under the Shari'ah Penal Code Order or if the suspect wants to make a confession by way of iqrar pursuant to the Shari'ah Court Evidence Order and the Shari'ah Court Criminal Procedure Order. In such a case, the case will be transferred to the Shari'ah court for prosecution by the Shari'ah prosecutor assisted by the Deputy Public Prosecutor if necessary. If not, then the prosecution will continue under the Penal Code in the civil court.

In other words, even though there are two provisions regarding the same offences in two different laws, a person would be charged only once, under one of the laws. ${ }^{22}$ Only time will tell how this arrangement works.

\section{Can such law be made and implemented in Malaysia?}

Assuming that a similar law were to be made in Malaysia, under the existing legal framework, could it be done and how? I am only looking at it from the legal perspective as it is, neutrally and professionally; like a judge delivering a judgment.

In discussing this issue, attention must be paid to the provisions of the Federal Constitution regarding the division of legislative powers between the Federation and the States. Under List I (Federal List), Ninth Schedule of the Federal Constitution, "criminal law" is a Federal matter and within the jurisdiction of the civil courts. On the other hand, "offences relating to precepts of Islam" as provided in List II (State List), Ninth Schedule of the Federal Constitution are within the legislative powers of the States and the jurisdiction of the Shari'ah Courts.

We will now look at the offences. We will find that some of the offences are "criminal law" offences which had existed in the Penal Code since 1936 and were in force at the time the Constitution was drafted. Certainly the words "criminal 
law" used by the framers of the Constitution refer mainly to the offences in the Penal Code. Otherwise, what else is "criminal law"? Furthermore, if not, then all the trials of offences under the Penal Code by the civil courts since Independence would be unconstitutional, null and void. That is a very ridiculous suggestion.

On the other hand, among the offences, there are offences which are not to be found in the Penal Code or any Federal law. In fact they have been provided for in the Shari'ah Criminal Offences Enactments of the States. Examples are sexual intercourse out of wedlock, accusing another person of committing zina and offences relating to intoxicating drink. It could be argued that those offences are not part of Federal "criminal law".

So, if those criminal offences under the Penal Code were to be made punishable with hudud and qisas punishments, that could only be done under a Federal law, i.e. as criminal law and not as "offences relating to precepts of Islam" as provided by List II (State List), Ninth Schedules of the Federal Constitution. There is no constitutional impediment to do so as a Federal law. Parliament may choose whatever punishments to be provided for criminal offences, including punishments according to Shari'ah. Done that way, they may be extended to Muslims and non-Muslims alike. Criminal law is under the jurisdiction of the civil courts. Civil courts have jurisdiction over Muslims and non-Muslims alike. For Parliament to make such law, no amendment to the Constitution is required and the bill could be passed by a simple majority. This situation is comparable to the law on Islamic banking and finance and takaful.

It must be stressed here that, as a Federal criminal law, it must apply to all, Muslims and non-Muslims alike, because it is "criminal law" and not "offences relating to precepts of Islam" as provided by List II (State List), Ninth Schedule of the Federal Constitution. If it is made applicable to Muslims only, it would be contrary to Article 8 as it is a discrimination on ground only of religion and therefore, unconstitutional, null and void. ${ }^{23}$

What about offences which are not to be found in the Penal Code or any Federal law which, in fact, had already been provided for in the Shari' ah Criminal Offences Enactments of the States, for example adultery? It could be argued that they are not "criminal law". To me, they may be made offences under the State law. However, to use the hudud punishment for them, there is a legal impediment, not by the Constitution but by Federal law ${ }^{24}$ which limits the punishments which could be legislated by the State Legislature. Only if the Federal Parliament is prepared to amend the Shari'ah Courts (Criminal Jurisdiction) Act 1965 to enable the State Legislature to provide for the hudud punishments, then the State Legislature may be able to do so. As a State law under List II (State List), Ninth Schedule of the Federal Constitution, the law is only applicable to Muslims and fall under the jurisdiction of the Shari'ah courts. There is no constitutional issue here. 
However, if it is done that way, then there will be a situation where some hudud offences carrying hudud punishments which form part of the Federal criminal law applicable to Muslims and non-Muslims and tried by the civil courts. Besides, there will be some hudud offences carrying hudud punishments which form part of the State law applicable only to Muslims and tried by the Shari'ah Courts. Is it sensible to have such a situation? I will leave it to you to decide.

Many people think that since the offences are hudud and qisas offences according to Shari'ah and "Islamic law" is under the jurisdiction of the State, therefore State Legislature may make such law. At the most, they are partially right. In Malaysia, any law made must be consistent with the Constitution. As I have said earlier, some of those offences lie within Federal and civil courts' jurisdiction. If they are made State law, clearly they are unconstitutional, null and void.

Even if it is done by the State Legislature, it cannot be made applicable to non-Muslims. The reason is that the Constitution only empowers the State Legislature to make laws to create offences applicable only to Muslims. So, if the State Legislature makes such law applicable to non-Muslims, the law is unconstitutional, null and void. Besides, Shari'ah Courts have no jurisdiction over non-Muslims. If the State Legislature were to empower the Shari'ah Courts to try non-Muslims, that law is also unconstitutional, null and void.

We often hear people saying that the law would be made applicable to Muslims only. Again, this is only partially right. The reasons are, first, criminal law is not personal law or "offences relating to precepts of Islam" as provided by List II (State List), Ninth Schedule of the Federal Constitution. Criminal law is a public law. The offences are offences against the state (or King, in England), not just against the victim. That is why it is the Public Prosecutor who prosecutes, on behalf of the state.

Secondly, as I have said, a law applying hudud punishments for criminal offences under the Federal jurisdiction to Muslims only would be inconsistent with Article 8 of the Federal Constitution as it is a discrimination on ground only of religion and therefore, unconstitutional, null and void. ${ }^{25}$

Thirdly, is it fair that if a Muslim steals the property of a non-Muslim he is subject to hudud punishment (amputation of hand) while if a non-Muslim steals the property of a Muslim he is only subject to imprisonment and/or fine? That is why Brunei made the offences of homicide, causing hurt, theft and robbery, for example, applicable to both Muslims and non-Muslims. In my view, to implement the hudud and qisas punishments in respect of those offences to Muslims only is not only unconstitutional but also unfair and unwise.

Another point that must be made is that at least there is one offence that cannot be provided for, whether in the Federal or the State law, because it will be 
unconstitutional. That is the offence of irtidad or a Muslim declaring himself as a non-Muslim. Under the Syariah Penal Code Order 2013 (Brunei) that offence is punishable with death. ${ }^{26}$ In Malaysia, such a provision would clearly be contrary to Article 11 of the Federal Constitution. ${ }^{27}$ Brunei has no constitutional constraint to make such a provision because it has no similar provision in her Constitution. In any event, the Sultan may just ignore it or amend it.

\section{Conclusion}

In my view, any law, no matter how good it is, if it is implemented without proper preparation, without taking into account the relevant factors or implemented inefficiently or unprofessionally, may lead to injustice. Good intention alone is not enough. Technical know-how, expertise and discipline are amongst the factors essential for the success of the implementation. The battle of Uhud is a good example: the intention was good but the discipline of the archers was lacking. They deserted their positions and scrambled for the spoils of war. That had enabled Khalid Ibn Walid to reorganise his troop and attack from the opposite direction. The Muslim army led by the Prophet (peace be upon him) himself lost the battle. Sunnah Allah works all the same no matter how pious the intention is. You have to do it right to get the right result. It is as simple as that.

The implementation of a law does not end with bringing it into force. What is more important is how it is done, what are the effects and the consequences, whether it leads to a better society, peace and tranquillity and whether it improves the level of justice in a country?

The goal of criminal law is not to punish, including with any particular punishment. The goal of criminal law is to prevent the prohibited acts, to establish public order and to administer justice in the event of contravention. Punishment is a tool to achieve that goal. A tool is not a goal. So, how it is used should be taken into account. The result will be the measure of its success or otherwise. In other words, the success of the implementation of hudud should not be measured merely by the fact that it is implemented or how many heads are decapitated, how many persons are stoned to death and how many hands are amputated. There is more to it.

We read that Umar Ibn Khattab, the Second Caliph suspended the application of hudud in time of famine. Question: Is that discretion a privilege given only to him and only in time of famine?

From what we read regarding what had happened in Pakistan, Nigeria and Sudan, since the implementation of the laws in question, we are still unable to say that it is going on smoothly and has achieved greater justice. We read about cases of injustice to rape victims who ended being convicted of the offence of adultery, because they could not produce the witnesses and they were pregnant. 
In Pakistan, this allegation was dismissed by Taqi Usmani, former judge of the Federal Shari'ah Court and the Supreme Court of Pakistan (Shariah Appellate Bench) adding that in his own experience of hearing cases concerning the Hudud Ordinances, first as a judge in the Federal Shari'at Court (FSC) and then in the Shari'at Appellate Bench of the Supreme Court of Pakistan, he did not come across even a single case where a woman who had filed a complaint of rape had instead been punished for adultery. ${ }^{28}$ We accept his words but we do not know about cases that do not go to him, especially in the interior areas. We do not know the real situation. But we know that because "there were demonstrations every day", the offence of rape was removed from the Hudud Ordinance and placed in the Penal Code again and tried by the civil court until now. I am quoting the words of Dr. Anwarul Haq, a Pakistani, who had spent about thirty years in the service of the Brunei Government, inter alia, drafting the Syariah Penal Code Order 2013 under discussion. Question: What was the reason for the daily demonstration and that only the offence of rape was removed from the Hudud Ordinance and placed in the Penal Code again? Certainly the demonstrations were in regard to the offence of rape. Why?

Regarding Nigeria, I asked Mr Justice Ibrahim Bukar, Chief Judge of the High Court, Federal Capital Territory, Abuja, Nigeria regarding Nigeria's experience. This is his reply to me through email on 10 December 2013, which I am quoting in full:

It is true that sharia legal system has been introduced in about 10 states in the northern part of the country. As you know Nigeria is a federation made up of 36 states and a federal capital Territory. The system was introduced in those states rather hastily and more for political gains than for its importance or the need for it. Added to that, the idea was conceived by the states and introduced in their respective territories without consultation or input from the federal government. In Nigeria, the police force, the prison and the law of evidence are under the exclusive legislative list; thus they are under the Federal Government. Without these apparatus, criminal justice cannot be effectively administered. That fact has affected the innovation. Secondly, the failure of [the government] to conduct proper orientation of the society to understand its scope and the necessity to make the non Muslim community within their territory to appreciate that the system apply only to Muslims has caused the system to be resisted. Most legal practitioners are not versed in sharia. That too is a minus to its successful take off. On the whole therefore, the sharia criminal justice is, because of these factors and more, cannot be said to be a successful venture. I fact, in recent times, one doesn't hear hudud applied on citizens. Most if not all of those that 
were pronounced have attracted appeals. Under the circumstance, my take to your questions is that, application of hudud is not, at least has not yet been fully accepted.

About ten years ago, at a conference at the Institute of Islamic Understanding Malaysia (IKIM), Professor Dr Ibraheem Sulaiman from the Centre of Islamic Studies, Ahmadu Bello University, Nigeria, amongst other things, said that the implementation of the Shari'ah in Nigeria came as a surprise and was done in a hurry.

In an article written by Aminu Adamu Bello, from the Faculty of Law, University of Abuja, Nigeria titled "Enforcement of Hudood Punishments under Islamic Law in Nigeria: Implications for a Plural Legal System", the author stated that "...data do not support an assertion that the enforcement of hudood penalties has had any effect on the nature of anti-social behaviour, especially armed robbery (hiraba), in these states. "29

According to the article "So far, no fewer than 23 persons are currently awaiting amputation and death by stoning in Bauchi State alone. Many of the convicts have remained in prison for about seven years without the ratification or otherwise of their sentences by the state government".

Why does the state government not ratify the sentences? Answer: "...these Governors have alleged that their inability to ratify the sentences was because the Shari'a Court judges 'hurriedly [passed] such sentences without following due legal process.",

The author even suggested a moratorium on the enforcement of hadd punishments in those States.

What about Sudan? I tried, including through academic friends, to get someone with first-hand knowledge of the situation in Sudan to enlighten us, but failed. What we read and see in the internet is worrying but, to be fair, we do not know the real situation. I'll settle for the following information.

First, I remember reading an article (of course I am unable to trace it now) that, for political reasons, one night President Jaafar Nameiri appeared on national television and announced that from 12.00 am that night, Shari'ah would be implemented fully in Sudan. The next morning everything was at a standstill. Police did not know what to do, prosecutors did not know what to do, lawyers did not know what to do and judges too did not know what to do. Lawyers rushed to bookshops looking for whatever books they could find on the subject.

Second, we also read that, in March 2013, Sudan's Deputy Chief Justice, Abdul Rahman Sharfi, made an announcement that if doctors refuse to amputate the hands of convicted criminals, the government would train judges to do it! He also suggested that doctors who refused to carry out such punishments could themselves face prosecution! 
We should not take what we see in Makkah and Madinah as an example. The people who go there are people who want to perform the pilgrimage, mostly once in a lifetime, bringing with them enough money that could have been saved for life, aiming to get the hajj mabrur and a great majority of them are elderly and have repented. Surely they would not commit criminal offences. On the other hand, do you not think that the rule that women must be accompanied by male mahram and the fact that to this day, in Saudi Arabia, women are not allowed to drive a car have something to do with their personal safety?

We are not in a position to assess the implementation of the law in Brunei yet because it has not come into force. Maybe in three or five years, we will be able to see how the implementation actually works and its impact. Does it lead to a higher degree of justice? Does it reduce the crime rate as expected? Will Brunei Darussalam, which is already peaceful be more peaceful? So far, the countries that have implemented the hudud punishments, such as Pakistan, Nigeria and Sudan still lag very far behind in these areas compared to countries that do not implement the hudud punishments such as Sweden, Norway, Iceland, Denmark and Japan in those areas. Perhaps, there are other factors.

The real challenge for Brunei is how the Shari'ah investigators, Shari'ah prosecutors and the Shari'ah judges will discharge their respective duties of investigating, prosecuting and trying the cases, at least at the initial stages. Their experience is limited to minor criminal cases like khalwat. When the law is implemented, suddenly they will have to deal with more complex cases like causing death, rape and causing bodily injuries which will also involve the introduction of scientific evidence unless they are only going to wait for the suspects to make confessions by way of iqrar which is most unlikely to happen. Would they be able to deal with the sudden influx of cases? Unlike the khalwat cases which usually end with the defendants pleading guilty, due to the seriousness of the punishments, these cases will be strenuously contested on all legal grounds imaginable, some of which could be foreign to the Shari'ah judges. We in the legal profession are anxious to read the judgments of the Shari'ah judges in those areas new to them. The judgments will reflect the standard of justice administered by them.

Maybe Brunei will prove something. We'll wait and see. At least, there is a difference in the case of Brunei. In Brunei, the introduction of hudud punishments is not motivated by political survival or to win the next general election. Works for the implementation had been going on for about thirty years and is still incomplete. We know that they have tried their best, and sincerely and have come up with a model they believe to be suitable considering the circumstances in Brunei. We wish them all the best.

Regarding Malaysia, it is important that we take all the relevant factors into account and if we decide to do it, we should do it right. 


\section{Notes}

* Tun Abdul Hamid Bin Haji Mohamad read law at the University of Singapore (LL.B (Hons)) in 1969. He was appointed as the Chief Justice of Malaysia in 2007 and retired in 2008. He is still active as Chairman of the Law Harmonising Committee of Bank Negara Malaysia, and a member of the Shari'ah Advisory Council of Bank Negara and the Securities Commission, he is also a member of the Judicial Appointments Commission. He can be contacted at tunabdulhamid@ gmail.com and http://www.tunabdulhamid.my/

1. This paper was presented as a public lecture at IAIS Malaysia on 11 February 2014, and is a slightly expanded version of the Malay version titled: "Pelaksanaan Hudud di Brunei: Perbezaan di Antara Brunei dan Malaysia” delivered on 7 January 2014.

2. I am using the word "hudud" irrespective whether it is in the singular or plural form.

3. Article 3 (Constitution of Brunei)

4. Article 4 (Constitution of Brunei)

5. Article 5 (Constitution of Brunei)

6. Article 6 (Constitution of Brunei)

7. Article 10 (Constitution of Brunei)

8. Article 11 (Constitution of Brunei)

9. Article 12 (Constitution of Brunei)

10. Article 19A (Constitution of Brunei)

11. Article 18 (Constitution of Brunei)

12. Article 19 (Constitution of Brunei)

13. Article 23 (Constitution of Brunei)

14. Article 31 (Constitution of Brunei)

15. I am grateful to Awang Haji Mohd. Yusree Hj. Junaidi, the Assistant Solicitor General of Brunei for the information.

16. Article 83 (Constitution of Brunei)

17. Article 83(4)(1) (Constitution of Brunei)

18. Article 86 (Constitution of Brunei)

19. Ninth Schedule List I (Federal Constitution)

20. Ninth Schedule List II (Federal Constitution)

21. Article 4 (Federal Constitution)

22. Section 252 SPCO 2013

23. 8(2) Except as expressly authorised by this Constitution, there shall be no discrimination against citizens on the ground only of religion, race, descent, place of birth or gender in any law...

24. Syariah Courts (Criminal Jurisdiction) Act 1965

25. 8(2) Except as expressly authorised by this Constitution, there shall be no discrimination against citizens on the ground only of religion, race, descent, place of birth or gender in any law....

26. Section 112 SPCO 2013

27. 11(1) Every person has the right to profess and practice his religion and, subject to Clause(4), to propagate it.

28. The Islamisation of Laws in Pakistan: The Case of Hudud Ordinances

29. I am grateful to Tasleem O.I. Akosile, a lawyer from Abuja, Nigeria for getting this article for me. 